\title{
Bioaccumulation of PCDD/Fs and PCBs in Ruditapes Philippinarum (Adams \& Reeve, 1850) in Vallona Lagoon (Italy)
}

\author{
Federica Cacciatore, Marina Amici, Giulia Romanelli, Valentina Bernarello, Gianluca Franceschini, Massimo \\ Gabellini and Claudia Virno Lamberti*
}

Italian Institute for Environmental Protection and Research (ISPRA), Italy

Submission: January 04, 2021; Published: February 01, 2021

*Corresponding author: Claudia Virno Lamberti, ISPRA, Via Vitaliano Brancati 60 Roma, Italy

Abstract

A Before-During-After environmental monitoring programme was scheduled to study possible alterations caused by the burial of an underground pipeline at the Vallona Lagoon in the Northern Adriatic Sea. In this context, bioaccumulation of polychlorinated dibenzodioxins and furans (PCDD/Fs), and polychlorinated biphenyls (PCBs) was assessed in Manila clams Ruditapes philippinarum, from November 2005 to June 2015, to monitor possible impacts of the burial of the pipeline due to sediment resuspension. Principal Component Analysis (PCA) results highlighted the prevalent bioaccumulation of Hexa-CBs during works, whilst their concentrations were similar when comparing ante to post operam monitoring phases. In addition, presence of Tetra- and Penta-CBs also characterized some samples in the post operam phase. On the contrary, the PCA applied to PCDD/Fs showed a homogeneous situation between the three monitoring phases, except for relatively high bioaccumulation values of some congeners in two different samples collected before works. Generally, PCDD/Fs showed a pattern of distribution of congeners typical of civil discharges, comparable with the overview of the area and mostly unrelated to the activities of burial of the pipeline.

Keywords: Biomonitoring; Adriatic sea; Po river delta; Clams; Before-during-after monitoring; Principal component analysis; Transitional waters

\section{Introduction}

Polychlorinated dibenzo- $p$-dioxins and furans (PCDD/Fs), and polychlorinated biphenyls (PCBs), are well known persistent organic pollutants (POPs), very resistant to degradation with enhanced chronic toxicity [1]. They can be considered as environmental indicators of anthropogenic activities, since they are always linked to activities including industrial, combustion and/or chemical processes [1-3]. PCDD/Fs and PCBs are generally found in environment as mixtures and the pattern of distribution of congeners could identify the civil or industrial source of contamination [3].

The Vallona Lagoon is a transitional area of about 1,150 ha located in the Po River delta that is the closure of the drainage basin of the largest and most important Italian watercourse. Moreover, Po River delta lagoons receive wastewaters from the most industrialized and densely inhabited regions of the northern Italy [4-6]. In the Vallona Lagoon, Manila clam Ruditapes philipinarum has a great economic importance, since it has been widely used for bivalve farming, but it has been also used as biomonitor organism to monitor several contaminants [7-9].

During 2007-2008, a pipeline was buried in the middle of the lagoon to connect structures of the first offshore LNG terminal in
Italy to facilities on land [10]. In view of this, an environmental monitoring programme was scheduled from 2005 to 2015, which consisted of three phases:

(i) before,

(ii) during and

(iii) after the construction of the structures.

The aim of the monitoring programme was to assess possible impacts of the burial of the pipeline, and in this context, bioaccumulation of PCDD/Fs and PCBs was assessed in $R$. philippinarum to monitor possible impacts in the Vallona Lagoon. Finally, this is the first study of PCDD/Fs biomonitoring, using Manila clams, in the Vallona Lagoon.

\section{Materials and Methods}

\section{Sampling strategy}

The study area was the Vallona Lagoon, NE Italy (Figure 1). Manila clams ( $R$. philippinarum) were collected by manual rake at four sites: two closer (L022 and L023) and two farther (L016 and L017) from the pipeline. Specimens were gathered in November 2005, February, April and July 2006 (ante operam phase), 
November 2006, February 2007, June and November 2008 (in opera phase), November 2010, June and November 2011, June and
November 2012, May and November 2013, June and November 2014, June and November 2015 (post operam phase).

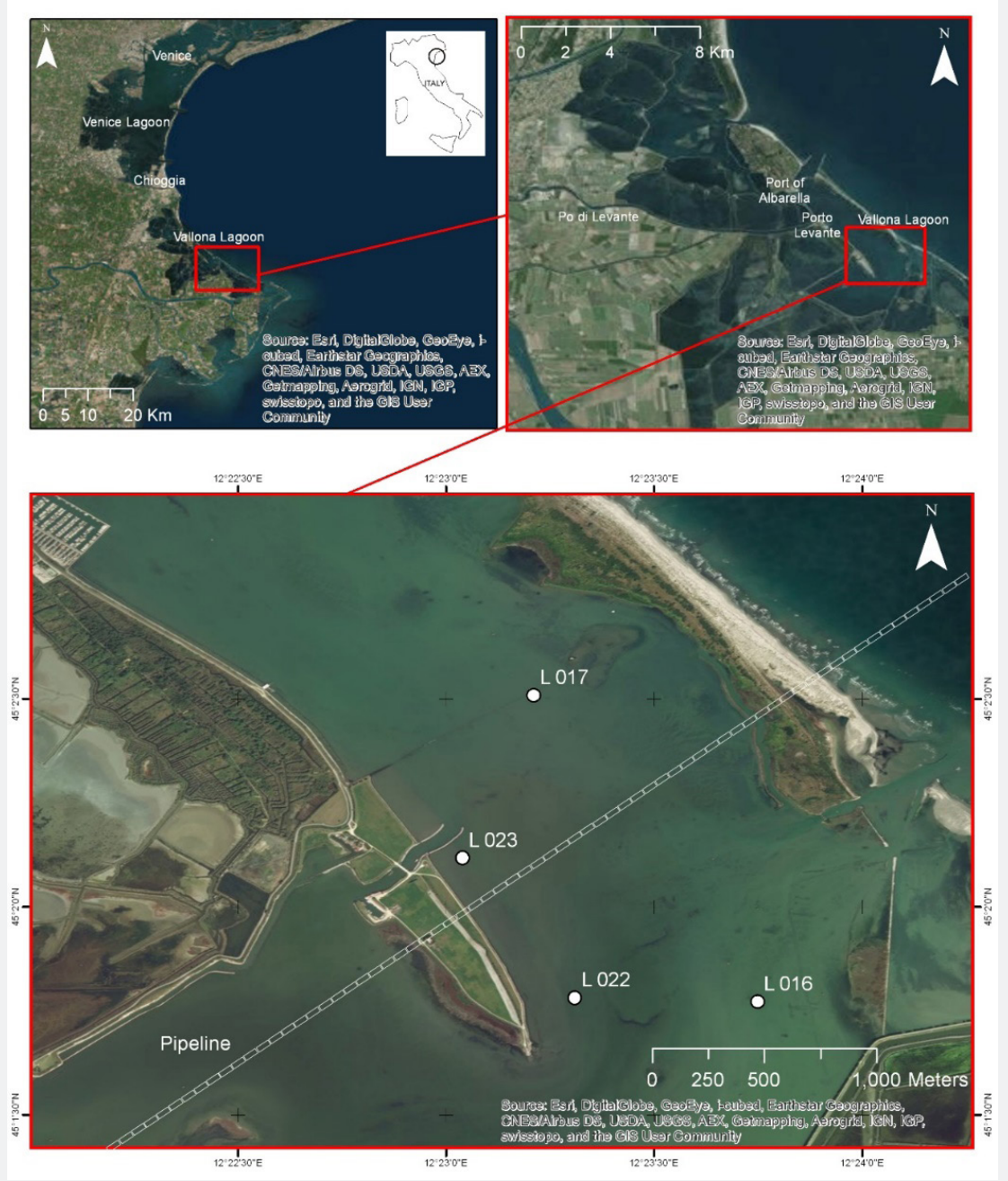

Figure 1: Maps of the Vallona Lagoon (Rovigo, NE Italy) with sampling sites of Manila clams.

After collection, about thirty clams per sample were measured and opened in laboratory; soft tissue were pooled (three pools of ten clams per sample), weighted, homogenized and maintained at $-20^{\circ} \mathrm{C}$ until analysis.

\section{Analysis of PCBs}

Sample was extracted in an ultrasonic bath with a mixture of n-hexane: dichloromethane 70:30 v/v. The clean-up of the extract was performed adding concentrated sulphuric acid and then eluting the organic phase through a Florisil cartridge with n-hexane. The recovered fraction, containing PCB 209 as internal standard, was analysed on a dual column Gas Chromatography coupled with Electron Capture Detector. PCB congeners analysed were the following: $28,31,35,52,77,81,101,105,110,118,126$, $128,138,153,156,169$, and 180.
Limit of quantitation of the method was $0.1 \mathrm{ng} / \mathrm{g}$ d.w.

\section{Analysis of PCDDs and PCDFs}

Sample added with a mixture of n-hexane:acetone 50:50 was extracted in Soxhlet for 24 hours. The organic extract was cleaned up adding concentrated acid sulphuric. The organic layer recovered was fractioned on a silica gel column and then on a basic alumina column. Instrumental analyses were performed by High Resolution Gas Chromatography coupled with High Resolution Mass Detector. PCDD/Fs congeners analysed were the following: 2,3,7,8 Tetra CDD, 1,2,3,7,8 Penta CDD, 1,2,3,4,7,8 Hexa CDD, 1,2,3,6,7,8 Hexa CDD, 1,2,3,7,8,9 Hexa CDD, 1,2,3,4,7,8,9 Hepta CDD, Octa CDD, 2,3,7,8 Tetra CDF, 1,2,3,4,6,7,8, 1,2,3,7,8 Penta CDF, 1,2,3,4,7,8 Hexa CDF, 1,2,3,6,7,8 Hexa CFD, 1,2,3,7,8,9 Hexa CDF, 2,3,4,7,8,9 Hexa CDF, 1,2,3,4,6,7,8 Hepta CDF, 1,2,3,4,7,8,9 Hepta CDF, Octa CDF. 
Limit of quantitation of the method for the different Results compounds ranged between 0.05-1 pg/g w.w.

\section{Statistical analysis}

Principal component analysis (PCA) was applied on PCBs (grouped by Tri-, Tetra-, Penta-, Hexa- and HeptaCBs) andPCDD/ Fs (grouped by Tetra-, Penta-, Hexa-, Hepta-, Octa- CDD/Fs) analysed in clams to elucidate bioaccumulation pattern. Statistical processing was performed by using Software R studio [11]. Levels of PCDD/Fs found in Manila clams depicted higher
values mostly in the ante operam phase (Figure 2), whilst PCBs bioaccumulation, mostly Hexa-CB, resulted higher at the end of in opera phase (Figure 3). However, PCBs concentrations returned quite similar to ante operam conditions at the end of the post operam phase.

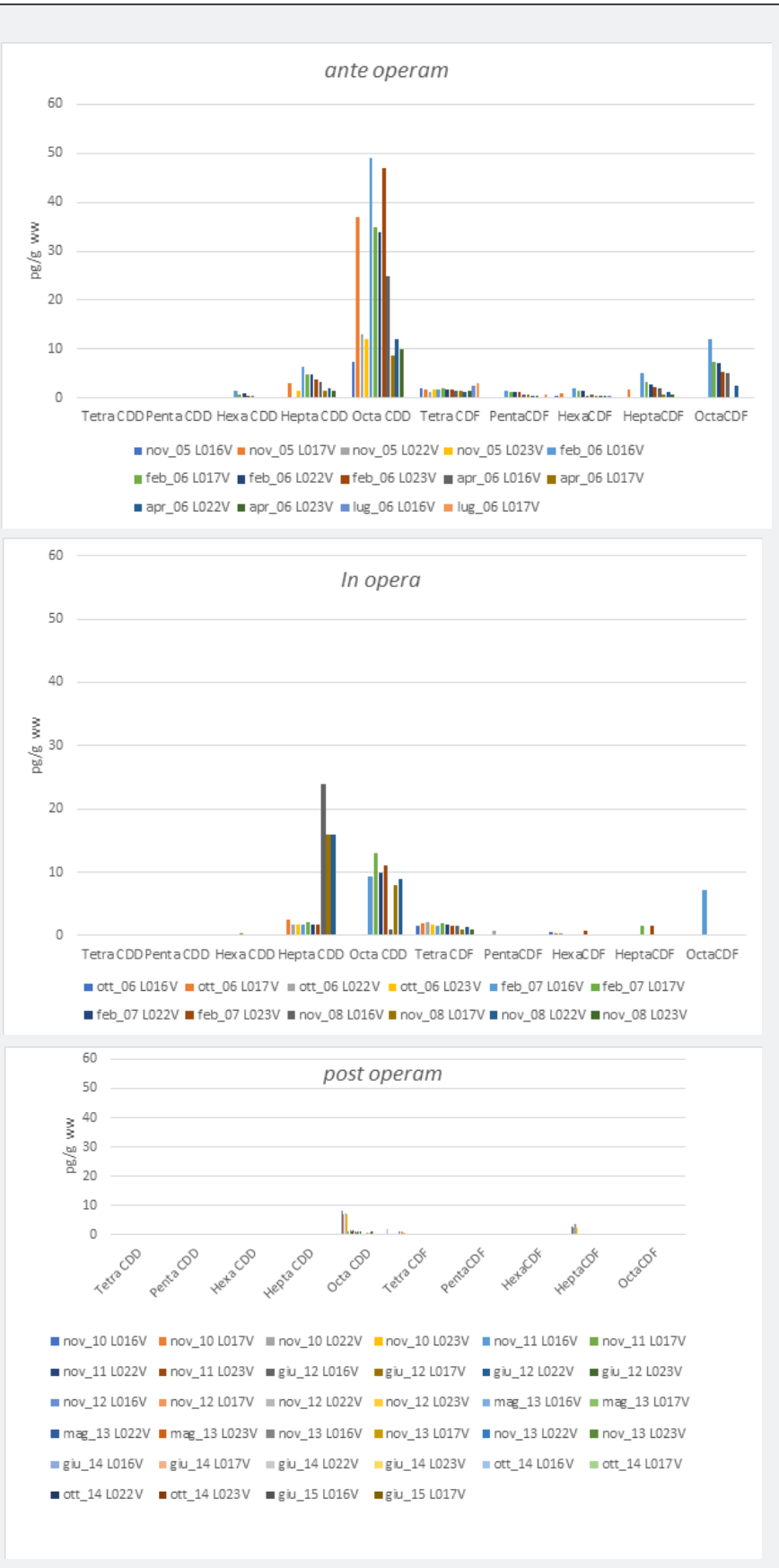

Figure 2: PCDD/Fs (grouped by Tetra-, Penta-Hexa-, Hepta-, Octa- CDDs/Fs) levels in R. philippinarum samples from the Vallona Lagoon before (ante operam), during (in opera), and after (post operam) pipeline burial activities. 


\section{International Journal of Environmental Sciences \& Natural Resources}

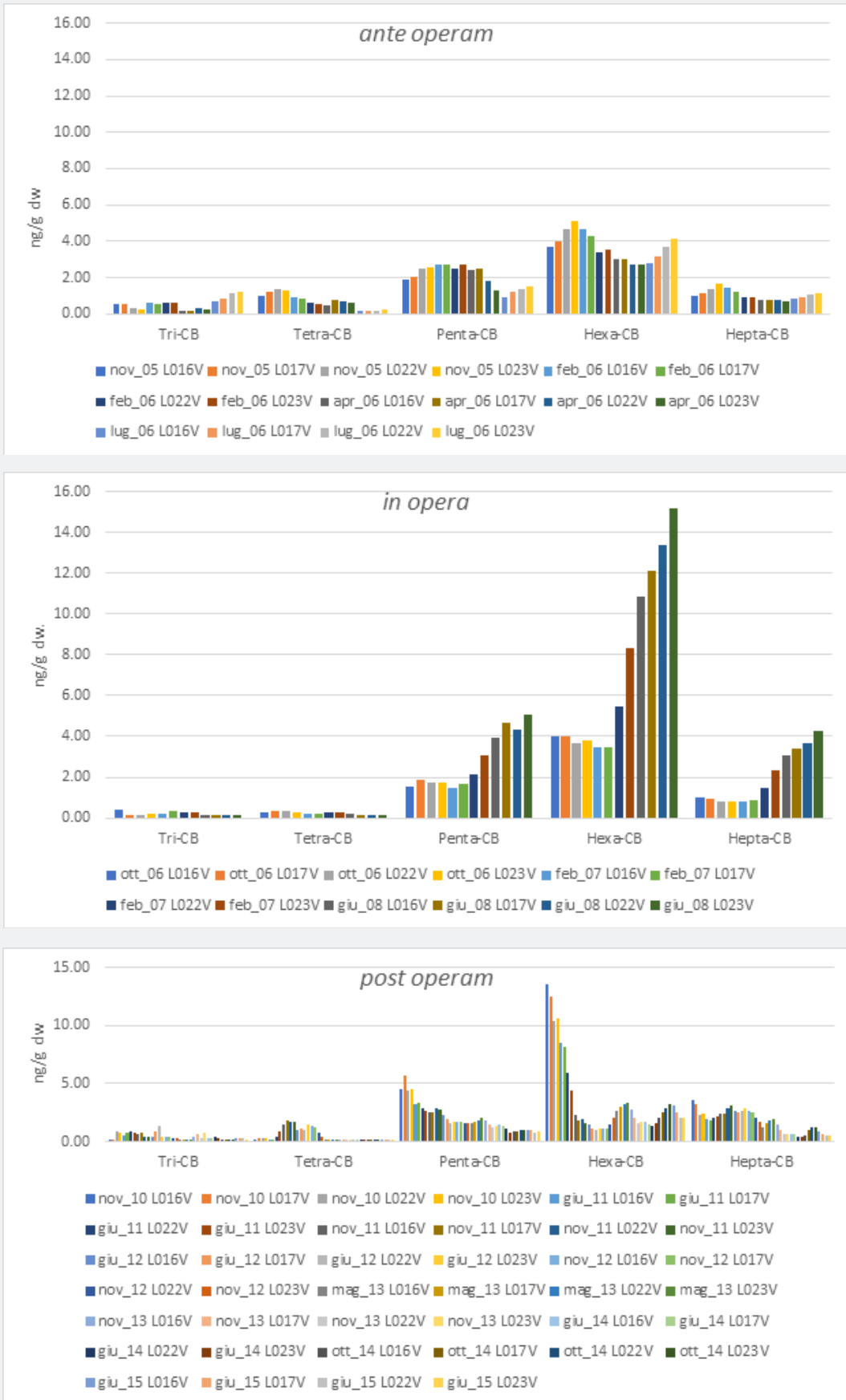

Figure 3: PCBs (grouped by Tri-, Tetra-, Penta-, Hexa- and HeptaCBs) levels in R. philippinarum samples from the Vallona Lagoon before (ante operam), during (in opera), and after (post operam) pipeline burial activities.

The distribution of the PCDD/Fs concentrations (Figure 4a) according to the first and second components accounted for $59.4 \%$ and $12.9 \%$ of the total variance, whilst PCBs levels accounted for $49.8 \%$ and $29.5 \%$ (Figure $4 \mathrm{~b}$ ). PCDD/Fs results of PCA display quite a good overlapping between clams sampled during ante and post operam phases, even if some samples of the first phase well differed from their group for Hexa-CDDs and Octa-CDDs. Moreover, post operam samples differed from all the other groups.
In addition, PCBs results of PCA are homogeneous in ante operam phase without peculiar groups of characterizing congeners. Indeed, some in opera samples well differed for HexaCBs. Finally, most of the post operam samples overlapped those from ante operam. Only two groups of post operam samples well differed, being the first characterized by Penta-CBs and the former by Tetra-CBs. 


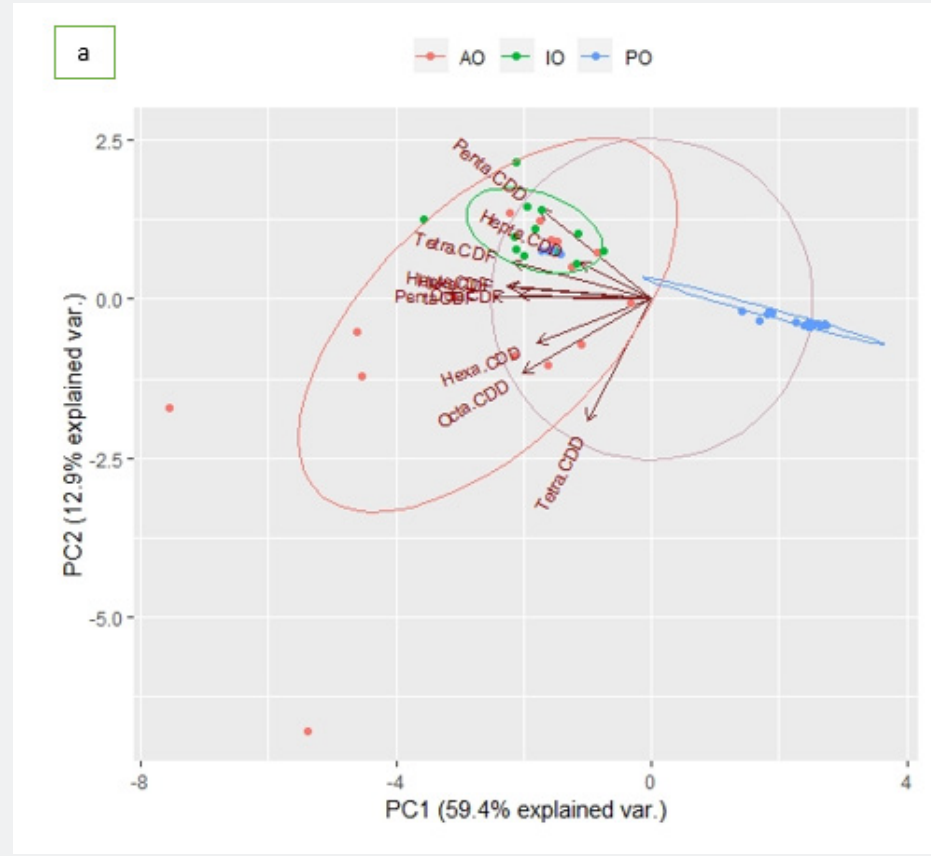

b

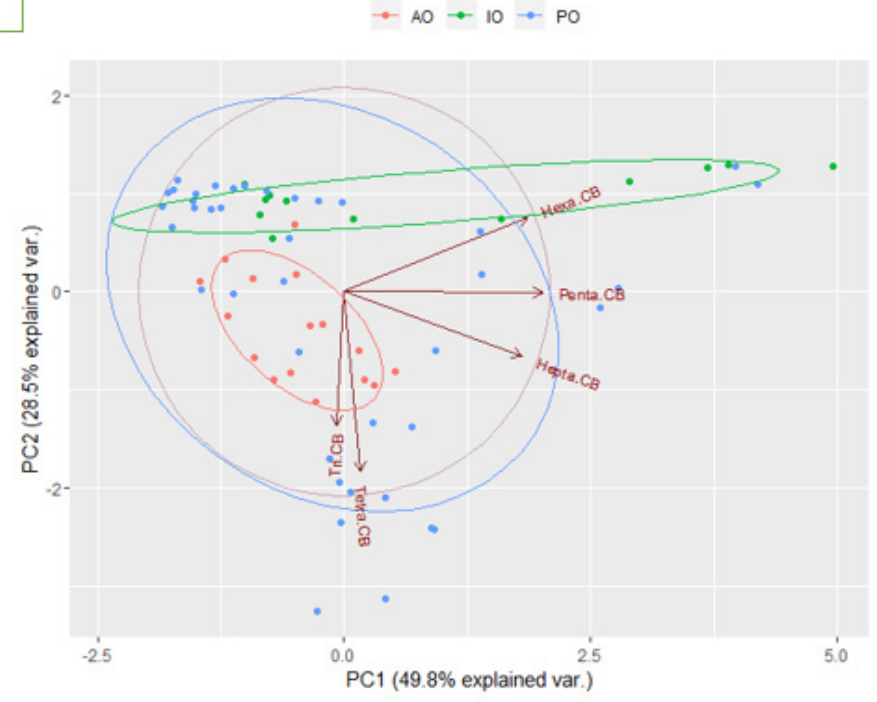

Figure 4: Biplot of the scores of all clam samples and the loading of a) PCDD/Fs (grouped by Tetra-, Penta, Hexa-, Hepta-, Octa- CDD/Fs) and b) PCBs (grouped by Tri-, Tetra-, Penta-, Hexa- and HeptaCBs). (AO = ante operam, IO = in opera, PO = post operam).

\section{Discussion and Conclusion}

PCDD/Fs and PCBs concentrations in Manila clams $R$ philippinarum sampled during the BDA monitoring for a pipeline construction in the Vallona Lagoon showed quite low levels when compared with other transitional areas with medium to low pollution impact [12-14]. Moreover, TEQ values were always lower than $8 \mathrm{pg} / \mathrm{g}$ w.w. that is the European limit in molluscs for human consumption (Reg. EC 1881/2006). However, the biomonitoring results displayed higher PCB levels, especially Hexa-CBs and Penta-CBs, during the end of the post operam phase, which persisted for a period after the burying of the pipeline, until they finally come back similar to the ante operam conditions. On the contrary, PCDD/Fs showed higher levels before the pipeline burying, whilst in the other two phases no substantial bioaccumulation phenomena were found. Generally, a profile of OctaCDD and light furans predominated all over the study, which is mainly related to civil combustion $[1,3]$. 
The Vallona Lagoon is a complex ecosystem influenced by the Po River, which drains huge amounts of nutrients and contaminants from intensely cultivated, and highly industrialized inland areas of the Northern Italy [14]. The human influence also consists of local contamination, although in a smaller quota [8]. In this context, biomonitoring of PCDD/Fs and PCBs in the Vallona Lagoon highlighted the effects of pipeline burial in increasing some PCB congeners at the end of the working phase, probably linked to the use of working machines. However, a pattern of distribution of PCDD/Fs congeners typical of civil discharges, also occurred before and after works, and they are generally comparable with the overview of the area and mostly unrelated to the activities of burial of the pipeline.

The environmental monitoring activities are necessary to assess the main possible impacts associated with human activities, such as the burial of a pipeline in very sensitive and complex ecosystems as coastal lagoons. The adopted monitoring strategy is confirmed to be successful when coupled with statistical analyses that emphasize each monitoring phases, such as PCA analyses. Indeed, they allowed to detect the fingerprints of contaminations and to compare before during and after monitoring phases at the same time.

Pipeline works slightly influenced PCDD/Fs and PCBs levels in Manila clams in the Vallona Lagoon, and they quite disappeared after a very short period, displaying a general anthropic influence from other contamination sources in the area [15].

\section{References}

1. De Souza Pereira M (2004) Polychlorinated dibenzo-p-dioxins (PCDD), dibenzofurans (PCDF) and polychlorinated biphenyls (PCB): main sources, environmental behaviour and risk to man and biota. Quím Nova 27(6): 934-943.

2. Bayarri S, Turrio Baldassarri L, Iacovella N, Ferrara F, di Domenico A (2001) PCDDs, PCDFs, PCBs and DDE in edible marine species from the Adriatic Sea. Chemosphere 43(4-7): 601-610.

3. Frignani M, Bellucci L, Carraro C, Favotto M (2001) Accumulation of polychlorinated dibenzo-p-dioxins and dibenzofurans in sediments of the Venice Lagoon and the industrial area of Porto Marghera. Mar Pollut Bull 42(7): 544-553.
4. Giani M, Djakovac T, Degobbis D, Cozzi S, Solidoro C, et al. (2012) Recent changes in the marine ecosystems of the northern Adriatic Sea. Estuar. Coast Shelf Sci 115: 1-13.

5. Vincenzi S, De Leo GA, Munari C, Mistri M (2014) Rapid estimation of potential yield for data-poor Tapes philippinarum fisheries in North Adriatic coastal lagoons. Hydrobiologia 724: 267-277.

6. Stefani F, Casatta N, Ferrarin C, Izzotti A, Maicu F, et al. (2018) Gene expression and genotoxicity in Manila clam (Ruditapes philippinarum) modulated by sediment contamination and lagoon dynamics in the Po river delta. MERE 142: 257-274.

7. Casatta N, Stefani F, Pozzoni F, Guzzella L, Marziali L, et al. (2016) Endocrine-disrupting chemicals in coastal lagoons of the Po River delta: sediment contamination, bioaccumulation and effects on Manila clams. ESPR 23(11): 10477-10493.

8. Maggi C, Berducci MT, Di Lorenzo B, Dattolo M, Cozzolino A, et al (2017) Temporal evolution of the environmental quality of the Vallona Lagoon (Northern Mediterranean, Adriatic Sea). Mar Pollut Bull 125(12): 45-55.

9. Cacciatore F, Bernarello V, Boscolo Brusà R, Sesta G, Franceschini G, et al. (2018) PAH (Polycyclic Aromatic Hydrocarbon) bioaccumulation and PAHs/shell weight index in Ruditapes philippinarum (Adams \&amp; Reeve, 1850) from the Vallona lagoon (northern Adriatic Sea, NE Italy). Ecotoxicol Environ Saf 148: 787-798.

10. Virno Lamberti C, Tomassetti P, Ceracchi S, Gabellini M (2020) Water Column Study in the Monitoring Plan of the First Italian Offshore LNG Terminal. Int J Environ Sci 26(3): 556187.

11. R Core Team (2019) R: A language and environment for statistical computing. R Foundation for Statistical Computing, Vienna, Austria.

12. Guerzoni S, Racanelli S (2003) La laguna ferita, uno sguardo alla diossina e agli altri inquinanti organici persistenti (POP) a Venezia. Libreria Editrice Cafoscarina, Venezia.

13. Boscolo Brusà R, Cacciatore F, Berto D, Giani M (2007) Polychlorinated biphenyls in clams Tapes philippinarum cultured in Venice Lagoon (Italy): Contamination levels and dietary exposure assessment. Food Chem Toxicol 45(6): 1065-1075.

14. Colakoğlu S, Künılı İE, Colakoğlu F (2020) Bioaccumulation monitoring of chemical contaminants in mussels Mytilus galloprovincialis from the southern coast of the Marmara Sea, Turkey. Turk J Vet Anim Sci 44: 235-243.

15. Romano S, Langone L, Frignani M, Albertazzi S, Focaccia P, et al. (2013) Historical pattern and mass balance of trace metals in sediments of the northwestern Adriatic Sea Shelf. Mar Pollut Bull 76(1-2): 32-41.

This work is licensed under Creative Commons Attribution 4.0 License DOI:10.19080/IJESNR.2021.27.556203

\section{Your next submission with Juniper Publishers} will reach you the below assets

- Quality Editorial service

- Swift Peer Review

- Reprints availability

- E-prints Service

- Manuscript Podcast for convenient understanding

- Global attainment for your research

- Manuscript accessibility in different formats ( Pdf, E-pub, Full Text, Audio)

- Unceasing customer service

Track the below URL for one-step submission https://juniperpublishers.com/online-submission.php 